\title{
Internalization Of Living VAlue Education Program (LVEP) As A BASEd OF DEVELOPING CONFLICT RESOLUTION MODEL
}

\author{
Wasis Suprapto $^{1)}$, Bunyamin Maftuh ${ }^{2)}$ Helius Sjamsuddin $^{3)}$ Elly Malihah $^{4)}$ \\ 1) STKIP Singkawang, Singkawang, Indonesia \\ E-mail: wasissoeprapto@yahoo.com \\ 2) Universitas Pendidikan Indonesia, Bandung, Indonesia \\ E-mail:bmaftuh@yahoo.co.id \\ 3) Universitas Pendidikan Indonesia, Bandung, Indonesia \\ E-mail: heliussjamsuddin@yahoo.com \\ 4) Universitas Pendidikan Indonesia, Bandung, Indonesia \\ E-mail: ellyms@upi.edu
}

\begin{abstract}
Violence become a serious problem in this country. All parties including students have been involved in this swirl of problems. The phenomenon of violence in the educational environment can be minimized by internalizing the Living Value Education Program (LVEP) in learning activities. LVEP internalization is carried out as a reference basis in developing resolution models in social studies learning. This article focuses on examining (1) the process of internalizing values in social studies learning, (2) the importance of including LVEP in the learning process, and (3) making LVEP the basis for developing a conflict resolution model. Articles are reviewed using literature study. The results showed that (1) the process of internalizing values in social studies learning was carried out in order to prepare students to become good citizens. (2) LVEP contains universal values such as peace, respect, love, cooperation, happiness, honesty, humility, responsibility, simplicity, tolerance, freedom and unity which can be used as a reference in classroom learning activities. (3) LVEP can be used as a reference in developing a conflict resolution model because it contains values of peace-loving, tolerance, and upholds the value of national unity and integrity.
\end{abstract}

Keywords: LVEP; Conflict Resolution Model; Social Studies

\section{INTRODUCTION}

Child abuse is still a frightening specter in Indonesia. Even though the government has issued very strict rules to break the chain of violence by issuing Law Number 35 of 2014 concerning Child Protection. Article 76C, for example, explains four consequences of acts of violence, namely:

"(1) Witness is imprisoned for a maximum of 3 years 6 months and / or a fine of 72 million, (2) if the child is seriously injured, he will be sentenced to a maximum imprisonment of 5 years and / or a fine of 100 million. , (3) if the dead child would be convicted imprisonment of 15 years and or a fine of 3 billion, and (4) if the perpetrator is a parent will be given an additional onethird of the criminal provisions of paragraphs 1,2 , and 3 .

Referring to article 76C above shows that the criminal sanctions that will be received by someone are quite heavy if they are proven to have committed acts of violence. However, the fact is that cases of violence against children are increasingly worrying every day. Data from the Ministry of Women's Empowerment and Child Protection (PPPA) explains that the number of child violence in 2020 reached 4,116 or the highest compared to the previous year. Violence against children includes 1,111 physical violence, 979 psychological violence, 2,556 sexual violence, 346 neglect, 73 crimes of trafficking in persons, and 68 exploitation (Kamil, 2020). This data becomes a reference for the complexity of cases of violence against children in Indonesia. 
In its development, violence against children occurs in various spheres including education. The education sector also plays a role in contributing to the number of violence in this country. Fathurrohman (2020) explains that there are four perpetrators of violence in the education sector, namely the principal, teachers, students, and parents of students. Research shows $44 \%$ of teachers or principals do to students; $30 \%$ among students, $13 \%$ of students to teachers, $13 \%$ of parents to teachers or other students. Christiana (2019) found three forms of violence at the elementary level where $40 \%$ were done verbally, $25 \%$ physically, and $15 \%$ psychologically. The results of Wijayanti \& Agustinus's research (2019) conclude that forms of violence commonly practiced by teachers in junior high schools are threatening, scolding, cursing, cursing, and so on. Referring to these data, it can be seen that all elements in schools have the potential to become perpetrators of violence.

The problem of violence that occurs in Indonesia reflects aa portrait of sense of decency that is contrary to the values of life. Darmadi (2009) explains that the result of sense of decency leads behavior to wrong arrogant, namely by punishing people who are not necessarily wrong. Megawangi (2010), the moral crisis that occurred in Indonesia was marked by a low sense of nationalism with increased violence among adolescents, the use of harsh language, the emergence ofbehavior self-destructive, vandalism in public places, and garbage scattered in the environment. Hayati (2014) sees that moral problems arise due to mistakes in parenting, low levels of conduciveness, low moral considerations, shadows of materialism and greed, low knowledge moral. Referring to the three opinions, it can be seen that the violence that occurs is a reflection of the arrogant behavior of the perpetrator, a low sense of nationalism, and a person's low moral knowledge.

Important moral knowledge is owned by the next generation of a nation. Schiller \& Tamera (2002) once warned that leaving moral teachings would risk losing a piece of peace. A similar opinion was expressed by Lickona (2008) that not providing the young generation with moral understanding is a serious ethical failure in society. Both of these opinions explain that moral education is an important need to be taught to students.

The moral crisis is a serious threat to the social life of the Indonesian nation. This happens because all sectors are experiencing a moral crisis, both public officials, ordinary people, including students, experiencing the same problems. This condition prompted the government to issue policies to handle problems. In 2010 the government through the Ministry of Education and Culture (Kemendikbud) issued a National Character and Culture Education program so that graduates become individuals with character.

Efforts to minimize moral problems, especially violence, can be done by implementing the Living Value Education Program (LVEP). LVEP is mostly carried out at various related education levels. Prastiwi (2018) conducted research at the PAUD level in Yogyakarta showing that LVEP has played a role in increasing the religious and moral values, social emotional, and language of students. Sari \& An-Nisa (2020) developed an Integrative Thematic SSP and is proven to be able to increase the nationalism value of elementary school students. Asfahani (2020) studies that LVEP is proven to increase understanding and awareness of supernormal students in MAN 2 Madiun City. Referring to the three research results, it can be seen that LVEP is flexible because it can be applied to various levels of education.

LVEP can be implemented in a number of ways. The development of a conflict resolution learning model can be put forward to realize LVEP. Research that examines the development of conflict resolution models has been carried out by both Maftuh (2005) and Ritiauw (2017). The results of both studies indicate that the conflict resolution model is used to minimize violence perpetrated by students. Both studies were conducted on the same subject, namely social studies. Therefore, the focus of this article will examine (1) the process of internalizing values in social studies learning, (2) the importance of including LVEP in the learning process, and (3) making LVEP the basis for developing a conflict resolution model.

\section{RESEARCH METHOD}

Research was analyzed using literature study method. Zed (2008) states that literature study is a series of activities related to methods of collecting library data, reading and taking notes, and managing writing materials. In practice, literature studies are obtained from various related sources such as journals, books, documentation, internet, and other relevant sources. The main thing that was studied was related to the internalization of the living value education program (LVEP) as a basis for developing a conflict resolution model. Data analysis of this literature study was carried out in the following steps (1) reviewing data to support the background of the problem (Nazir, 2014), (2) collecting relevant sources of study material (Arikunto, 2013), (3) citing related information (Nazir, 2014), (4) deduce the data from the information that has been cited

\section{RESULT AND DISCUSSION}

\section{A. RESULT}

\section{Internalization Value}

Internalization Internalization is a fairly common term heard in the world of education. The term is used to support learning activities. In each learning activity, the teacher will usually internalize the related values that must be conveyed in learning. The values that are internalized must be adjusted to the material and the output that the teacher wants to achieve in learning.

The term internalization has been used by several experts. Mulyasa (2012) sees it as a process of living and deepening values and norms so that they are embedded in individuals. Kalidjernih (2010) sees it as a learning process to tie oneself into the values and norms in society. Tafsir (2010) sees internalization as an attempt to incorporate knowledge and power into the person. Referring to the three opinions, it can be seen that internalization is 
actually a process of inserting values and norms so that they can be embedded in individuals.

Internalization of values and norms in a person is carried out through a series of stages. Muhaimin (2012) describes three stages, namely (1) transformation is carried out by conveying which values are good and bad by the teacher; (2) transactions are carried out through two-way communication between teachers and students. At this stage, it emphasizes the physical side or what the teacher does; (3) Transinternalization is carried out by involving physical and psychological elements of teachers and students. Munif (2017) concocts six stages, namely (1) exemplary, (2) habituation, (3) ibrah or taking lessons and amtsal or parables, (4) giving advice, (5) giving promises and threats, (6) discipline. Both of these opinions can be used for the value internalization process. However, for learning activities that are limited to certain studies, the value internalization process tends to use Muhaimin's study.

In practice, there are many values that can be internalized in learning in schools. The government through the Ministry of National Education (2009) issued 18 values that can be applied in learning activities, namely religious, honest, tolerance, discipline, hard work, creative, independent, democratic, curiosity, national spirit, love for the country, respect for achievement, friendly or communicative, peace-loving, fond of reading, environmental care, social care, and responsibility. In 2017 the Ministry of Education and Culture has also issued the Strengthening Character Education (PPK) movement which contains five main values, namely religious, nationalist, integrity, independence, and mutual cooperation with thesub-values following:

a. Religious values through peace-loving attitudes, tolerance, respect for religious differences and trust, persistence, self-confidence, cooperation between religions and beliefs, anti-bullying and violence, friendship, sincerity, not imposing one's will, loving the environment, protecting the small and the marginalized.

b. Nationalist values through an attitude of appreciation of the nation's own culture, safeguarding the nation's cultural wealth, being willing to sacrifice, being superior and achieving, loving the country, protecting the environment, obeying the law, discipline, respecting cultural, ethnic and religious diversity.

c. The value of integration is through an attitude of responsibility as a citizen, actively involved in social life, through consistency in actions and words based on truth. A person with integrity also respects the dignity of the individual (especially people with disabilities), is able to show exemplary

d. independent values through a good work ethic, tough, fighting, professional, creative, courageous, and a lifelong learner.

e. The value of mutual cooperation through an attitude of respect for others, being able to work together, being inclusive, being able to commit to joint decisions, deliberation to reach a consensus, helping to help, having empathy and a sense of solidarity, antidiscrimination, anti-violence, and an attitude of volunteerism

In principle, the five sub-values of the five core values this can serve as a basis for model development. However, this value is also selected according to need. Based on the results of the analysis, it is known that there are only ten sub-values derived from two main values, namely religious and mutual cooperation. Religious values include the sub-values of tolerance, love of peace, antiviolence, not imposing one's will, cooperation between followers of religions and beliefs. The values of mutual cooperation include the value of respect, deliberation, mutual assistance, anti-discrimination, and committees on decisions joint. At least the ten values can be used to represent the value of KDP.

2 The Living Value Educational Program (LVEP) in the Learning Process

LVEP can be put forward in order to implement morality education in students. LVEP is a program that offers practical empirical and methodological value activities for educators, facilitators, social workers, parents and child assistants to help them provide opportunities for children and adolescents to explore and develop value education (Dianne \& Pilar, 1994). Tilmann \& Diana (2004) gave three notes from LVEP, namely (1) teaching respect and honor to every human being, (2) paying attention to the value and ability to create if given the opportunity, and (3) upholding mutual respect and affection between people, students, teachers, and the environment.

Referring to the two opinions above, it can be seen that LVEP has a positive charge which is applied in the world of education. LVEP can help and develop value education. The form of value education can be seen from the main assumptions of LVEP which provide studies for humanizing humans. Therefore, LVEP contains universal values which include the values of peace, respect, love, cooperation, happiness, honesty, humility, responsibility, simplicity, tolerance, freedom and unity (Tillman, 2000). This universal value is important to apply to areas that are prone to conflict and have multi-ethnic population conditions such as Indonesia.

History has recorded that various horizontal conflicts have occurred in this country. Conflicts with racial nuances (ethnicity, race, and religion) and separatist actions are some of the important events that occurred in Indonesia. One of theconflict incidents to be interesting studied is inter-ethnic conflict. This incident occurred in several regions in Indonesia. Welianto (2020) notes that during the 14 years post-reformation there have been 2,398 cases of violence and discrimination. The data released by the Denny JA Foundation explains that $65 \%$ of cases are due to religious violence, $20 \%$ ethnic violence, $15 \%$ violence gender, and $5 \%$ sexual orientation violence. 
In social life there has been communal violence. West Kalimantan is one of the provinces that is prone to experiencing this problem of violence. Data from Kristianus (2011) states that many districts / cities have been the places for inter-ethnic conflicts. Conflicts in these areas involved four major ethnic groups such as Dayak, Madurese, Chinese and Malay with the following details:

TABLE I.

CONFLICT IN WEST KALIMANTAN

\begin{tabular}{|c|c|c|c|}
\hline No & Year & Place & Ethnic \\
\hline 1 & $\begin{array}{c}1966- \\
67\end{array}$ & $\begin{array}{l}\text { Sambas, Pontianak, } \\
\text { Sanggau, Sintang, } \\
\text { Ketapang }\end{array}$ & $\begin{array}{c}\text { Dayak vs } \\
\text { China }\end{array}$ \\
\hline 2 & 1968 & $\begin{array}{l}\text { Anjungan Kab. } \\
\text { Pontianak }\end{array}$ & $\begin{array}{c}\text { Dayak vs } \\
\text { Madura }\end{array}$ \\
\hline 3 & 1976 & $\begin{array}{l}\text { Sungai Pinyuh- } \\
\text { Pontianak District }\end{array}$ & $\begin{array}{c}\text { Dayak vs } \\
\text { Madura }\end{array}$ \\
\hline 4 & 1977 & $\begin{array}{l}\text { Singkawang Kab } \\
\text { Sambas }\end{array}$ & $\begin{array}{c}\text { Dayak vs } \\
\text { Madura }\end{array}$ \\
\hline 5 & 1979 & Sambas & $\begin{array}{c}\text { Dayak vs } \\
\text { Madura }\end{array}$ \\
\hline 6 & 1982 & $\begin{array}{l}\text { Pak Kucing, Sambas } \\
\text { District }\end{array}$ & $\begin{array}{c}\text { Dayak vs } \\
\text { Madura }\end{array}$ \\
\hline 7 & 1983 & $\begin{array}{l}\text { Ambawang-Pontianak } \\
\text { District }\end{array}$ & $\begin{array}{c}\text { Dayak vs } \\
\text { Madura }\end{array}$ \\
\hline 8 & 1992 & $\begin{array}{l}\text { Pak Kucing-Sambas } \\
\text { District }\end{array}$ & $\begin{array}{c}\text { Dayak vs } \\
\text { Madura }\end{array}$ \\
\hline 9 & 1993 & Pontianak City & $\begin{array}{c}\text { Dayak vs } \\
\text { Madura }\end{array}$ \\
\hline 10 & 1994 & $\begin{array}{l}\text { Tubang Titi: Ketapang } \\
\text { District }\end{array}$ & $\begin{array}{c}\text { Dayak vs } \\
\text { Madura }\end{array}$ \\
\hline 11 & 1996 & $\begin{array}{l}\text { Sanggau Ledo } \\
\text { Bengkayang District }\end{array}$ & $\begin{array}{l}\text { Dayak vs } \\
\text { Madura }\end{array}$ \\
\hline 12 & 1997 & $\begin{array}{l}\text { Sambas, Pontianak, } \\
\text { Sanggau Kapuas, } \\
\text { Pontianak City }\end{array}$ & $\begin{array}{c}\text { Dayak vs } \\
\text { Madura }\end{array}$ \\
\hline 13 & 1999 & Sambas & $\begin{array}{l}\text { Melay vs } \\
\text { Madura }\end{array}$ \\
\hline 14 & 1999 & $\begin{array}{l}\text { Sambas District and } \\
\text { Pontianak City }\end{array}$ & $\begin{array}{l}\text { Melay vs } \\
\text { Madura }\end{array}$ \\
\hline 15 & 2000 & $\begin{array}{l}\text { Sei Duri: Kubu Raya } \\
\text { District }\end{array}$ & $\begin{array}{c}\text { Melay vs } \\
\text { Dayak }\end{array}$ \\
\hline 16 & 2007 & Pontianak City & $\begin{array}{c}\text { Melay vs } \\
\text { China }\end{array}$ \\
\hline 17 & 2008 & Singkawang City & $\begin{array}{c}\text { Malay vs } \\
\text { China }\end{array}$ \\
\hline
\end{tabular}

Source: Kristianus (2011)

Referring to table 2 above, it can be seen that West Kalimantan has a fairly long track record of conflict. Every district / city in West Kalimantan has the potential to experience inter-ethnic conflict. Districts such as Sambas, Bengkayang, Sanggau, Pontianak or Kubu Raya today, Kota Singkawang and Pontianak are areas prone to conflict. The data shows that all major ethnicities such as
Chinese, Dayak, Madurese and Malay have been involved in the conflict. This is a common concern so that a similar conflict does not happen again at another time.

\section{Learning Models}

Before examining learning models, it is better to look at some of the terms commonly used in the education world. Terms such as models, methods, strategies, techniques and tactics are often used in learning activities. However, it is not uncommon for a researcher to seem less observant in distinguishing some of these terms. The use of these terms seems to have something in common with each other. Even though the term actually has a different essence. Joyce \& Weil (2009), Sudrajat (2008), Komalasari (2010), and Rusman (2011) have similarities in studying learning models. Basically the learning model is a systematic learning plan which includes learning approaches, methods, techniques and tactics as follows:

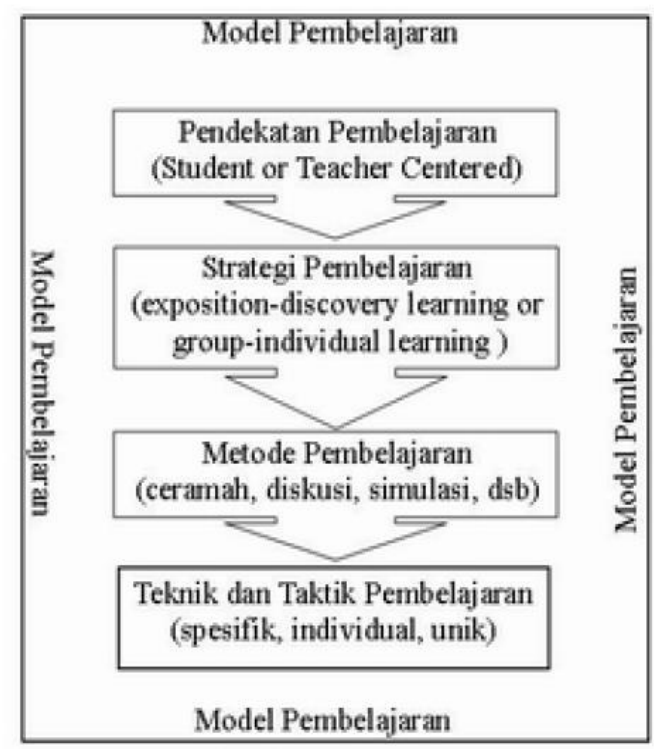

Figure 1. Components of the Learning Process

Based on these opinions, it can be seen that the use of the terms models, strategies, methods, techniques and tactics is different from one another. Sudrajat (2008) describes the approach as a learning orientation that focuses on teachers or students, the strategy isexpositiondiscovery learning and group-individual, the method is a way to achieve the goal, the technique is the method while the tactic is the method of applying the method. Therefore, the development of a conflict resolution model includes a systematic learning design to achieve certain goals.

The learning model has several characteristics. Joyce \& Weil (2009) and Rusman (2011) provide four distinctive characteristics of the model, namely (1) having a supporting theory, (2) having specific goals, (3) having a role in improving learning activities, (4) having contents such as syntax or the sequence of the learning process, social systems, management principles, support systems, and instructional impacts and accompaniment impacts. 
These four characteristics are an inseparable part of developing a learning model.

\section{Conflict Resolution}

Opinions about conflict resolution studies are explained by several experts such as Weitzman \& Weitzman (in Merton \& Coleman, 2000: 197), Fisher (2001: 7) and Mindes (2006: 24). Weitzman \& Weitzman see conflict resolution as the act of solving problems collectively. Fisher sees it as an attempt to study the causes and effects of conflict and to build new, lasting relationships between hostile groups. Mindes sees the ability to resolve differences and is an important aspect of social and moral development that requires skills and judgment to negotiate, compromise and develop a sense of justice.

Referring to the three opinions above, it can be concluded that conflict resolution is an effort made by individuals or groups to solve problems together. Resolution serves to build new, lasting relationships between hostile groups. On the other hand, conflict resolution can also be a medium to improve negotiation skills, compromise, and a sense of justice among each other. As beings social, human conflicts will always be faced in navigating their lives. Therefore, conflict resolution must become a skill as an effort to maintain harmony among community members.

\section{B. DISCUSSION}

\section{Value Internalization in Social Studies Learning}

The process of internalizing values cannot be separated from the objectives of social studies learning. There are five objectives of IPS according to Permendiknas Number 22 of 2006 concerning Standard Content of Subjects, namely (1) introducing concepts to community life and the environment, (2) training logical and critical thinking, curiosity, inquiry, problem solving and skills in life, (2) 3) having commitment and awareness of social and human values (4) being able to communicate, cooperate, and compete in a pluralistic society at various levels. The analysis of the objectives of IPS was expressed by Barr (in Winataputra, 2010), namely social studies taught as citizenship transmission, taught as social sciences, and taught as reflective inquiry. Sumaatmadja (2001) examines the objectives of social studies so that students become more sensitive to social problems, have a positive mentality to overcome existing inequalities, and are skilled in overcoming daily problems.

Referring to the three opinions above, it can be concluded that the purpose of social studies learning is to educate students to be good citizens, obey the values and norms, sensitive and able to overcome existing problems, be able (communicate, collaborate, and compete in a pluralistic society). . To realize the objectives of social studies learning, it can be done by internalizing the related values. Basically, all values can be internalized in social studies learning. Tolerance, peace-loving, anti-violence, not imposing will, cooperation between religions and beliefs, respect, consensus agreement, help, antidiscrimination, and committees on decisions jointare some of the values that can be put forward in learning activities.

\section{LVEP in the social studies learning process}

The conflict resolution model is a forum for internalizing the value of LVEP. The process of internalizing values can be carried out in various subjects. Social studies as one of the subjects at the junior high school level are put forward for the process of internalizing these values. This condition occurs because the essence of social studies learning is not only focused on the transfer of knowledge but also the transfer of value (Mortela, 1994). Values will greatly contribute to the formation of moral knowing, moral feeling, and moral behavior (Lickona, 1991). A concept like this is needed to face all the challenges of the times in this modern era.

Since its inception, IPS has been set to become an adaptive subject. This condition is very possible because IPS comes from the integration of social science and humanities disciplines (National Council for the Social Studies or NCSS, 1994). In addition, social studies learning contains state ideology and related social problems that are presented scientifically (Somantri, 2001). Referring to these two opinions, it can be seen that IPS has more bargaining power because the study process can come from various related disciplines. Social studies lessons also contain state ideology which is used as the basis for fostering students to become good citizens. It is also important that IPS focus on studying social problems in society.

Social problems in Indonesia can be minimized by integrating the contents of the LVEP values. LVEP contains universal values such as peace, respect, love, cooperation, happiness, honesty, humility, responsibility, simplicity, tolerance, freedom and unity (Tillman, 2000). It is important to apply these universal values to areas that are prone to conflict and have multi-ethnic population conditions such as Indonesia.

\section{LVEP as a basis for developing a model for conflict resolution}

Development of a model for conflict resolution is something that is urgent to do. This condition cannot be separated from the two contexts of contemporary and historical problems. The context of the present problem has shown that violence has become a serious problem faced by the people Indonesian. Violence data as mentioned by Kamil (2020) shows four types of violence that often occur in the realm of education, both physical, psychological, sexual, neglect, trafficking and exploitation. This condition is also reinforced by the fact that historically Indonesia was a meeting place for various ideologies and interests.

Conflict issues are the responsibility of all parties, including the education sector. Education has a big share in reducing or minimizing these problems. This effort can be done by integrating conflict material with the subject 
matter of study. Social studies can be put forward because it examines various social problems in society (Permendiknas, Barr, and Sumaatmadja). Based on this analysis, it is known that violence is included in the subject matter of social conflict and the following syllabus of class VIII Junior High School:

TABLE II.

SYLLABUS OF CLASS VIII

\begin{tabular}{ll}
\hline Basic Competency & \multicolumn{1}{c}{ Main Material } \\
\hline $\begin{array}{l}\text { 3.2 Analyzing social } \\
\text { interaction in space } \\
\text { and its effects on } \\
\text { social and cultural life } \\
\text { and the development }\end{array}$ & $\begin{array}{l}\text { The influence of social } \\
\text { interaction (social } \\
\text { mobility) on the socio- } \\
\text { cultural life }\end{array}$ \\
$\begin{array}{l}\text { of national life } \\
\text { Presenting the results } \\
\text { of the analysis of the } \\
\text { influence of social } \\
\text { interaction in different } \\
\text { spaces on social and } \\
\text { cultural life as well as } \\
\text { the development of } \\
\text { national life }\end{array}$ & - Cocciety \\
\hline
\end{tabular}

Resources (Syllabus , 2017: 12-16)

Referring to table 2 above, it can be seen that violence can be included in studies of conflict and social integration. This material is the last study in class VIII semester one. Especially for conflict material, it only contains studies on the meaning, factors causing conflict, consequences of conflict, and how to handle conflict before entering into social integration studies (Mukminan et al., 2017). In this material there are things that are interesting to study, namely the material on how to deal with conflict is only studied in an outline. This condition is the basis for developing a model for conflict resolution at the junior high school.

Research that examines conflict resolution learning (PRK) has been carried out at various levels of education as follows:

TABLE III.

RESEARCH ON CRP

\begin{tabular}{lll}
\hline \multicolumn{1}{c}{ Level } & \multicolumn{1}{c}{ Researcher } & \multicolumn{1}{c}{ Results of } \\
\hline $\begin{array}{l}\text { Elementery } \\
\text { School }\end{array}$ & $\begin{array}{l}\text { Rodiah et al. } \\
(2017)\end{array}$ & $\begin{array}{l}\text { PRK can improve } \\
\text { social attitudes and } \\
\text { learning outcomes of } \\
\text { Elementery School }\end{array}$ \\
\hline Junior High & $\begin{array}{l}\text { Ritiauw } \\
\text { School }\end{array}$ & $\begin{array}{l}\text { Pela culture can be } \\
\text { used to instill conflict } \\
\text { resolution education } \\
\text { in Junior High School }\end{array}$ \\
& &
\end{tabular}

\begin{tabular}{lll}
\hline $\begin{array}{l}\text { Senior High } \\
\text { School }\end{array}$ & $\begin{array}{l}\text { Purwoko et al } \\
\text { (2016) and } \\
\text { Nadya et al } \\
(2020)\end{array}$ & $\begin{array}{l}\text { PRK is proven to be } \\
\text { effective in resolving } \\
\text { interpersonal conflicts } \\
\text { that occur between } \\
\text { students at Senior } \\
\text { High School }\end{array}$ \\
\hline College & Arifin (2020) & $\begin{array}{l}\text { Local culture is used } \\
\text { as the basis for PRK } \\
\text { to strengthen the } \\
\text { character of students }\end{array}$ \\
\hline
\end{tabular}

Source: compiled from various sources

Referring to Table 2 above shows that the CRP can be used as a reference for developing a conflict resolution model in social studies learning. The development of this model must refer to the opinion of Joyce \& Weil (2009) and Rusman (2011) that the model must have four aspects, namely: (1) have a supporting theory, (2) have specific goals, (3) play a role in improving learning activities, (4) ) has contents such as the sequence of the learning process, social systems, management principles, support systems, instructional impacts and accompaniment impacts.

However, in developing an LVEP-based conflict resolution model, it must return to two elements, namely LVEP itself and the content of conflict resolution. LVEP contains values such as peace-loving, tolerant, national unity and integrity. Meanwhile, conflict resolution is related to efforts to solve a problem collectively. A problem can be resolved if each individual can uphold the values of peace-loving, tolerance, unity and integrity as fellow children of the nation.

\section{IV.CONCLUSION}

Based on the results of the research and discussion, the following conclusions can be concluded:

1. Value internalization is indispensable in social studies learning in order to prepare students to become good citizens. This can be done by integrating values such as tolerance, peace-loving, anti-violence, not imposing will, cooperation between religions and beliefs, respect, deliberation, consensus, helping to help, antidiscrimination, and committees on decisions jointin social studies learning.

2. LVEP has an important urgency in social studies learning because it has universal values that are important to be applied to conflict-prone areas and have multi-ethnic population conditions such as Indonesia.

3. LVEP can be used as a reference in developing conflict resolution models in schools. The essence of 
developing an LVEP-based model is to turn students into peace-loving, tolerant, and uphold the values of national unity and integrity.

\section{REFERENCES}

Arifin, MH. 2020. The effectiveness of the role of local Arifin, MH. 2020. Efektivitas peranan budaya lokal dan penguatan karakter sebagai media pendidikan resolusi konflik pada mata kuliah pancasila dan kewarganegaraan. Kolaborasi Resolusi Konflik Vol.1, No. 2

Arikunto, S. (2013). Prosedur Penelitian: Suatu Pendekatan Praktik. Jakarta: Rineka Cipta

Asfahani. 2020. Pendidikan Anak Supernormal Dengan Pendekatan Living Values Education Program (Studi Kasus Kelas Akselerasi MAN 2 Kota Madiun). AlAdabiya: Jurnal Kebudayaan dan Keagamaan. Vol. 15, No. 1

Christiana, E. (2019). Identifikasi Bentuk Kekerasan dan Penangannya di Lingkungan Sekolah Dasar. Child Education Journal. Vol.1, No. 2 December 2019

Darmadi, H. 2009. Dasar Konsep Pendidikan Moral. Bandung: Alfabeta

Fathurrohman. 2020. Angka Kekerasan Siswa di Sekolah Capai 153 Aduan.

Hayati, AA. 2014. Pendidikan Nilai Moral Melalui Program Living Values Activities Dalam Pengembangan Karakter Siswa di SMA Plus Muthahari Bandung. https://adoc.pub/pendidikan-nilai-moral-melaluiprogram-living-values-activit.html

Joyce, B., Weil, M., \& Calhou, E. (2011). Models of Teaching: Model-Model Pengajaran. Yogyakarta. Pustaka Pelajar.

Kalidjernih, F. K. (2010). Kamus Study Kewarganegaraan, Perspektif Sosiologikal dan Political. Bandung: Widya Aksara.

Komalasari, K. (2010). Pembelajaran Kontekstual Konsep dan Aplikasi. Bandung: Refika Aditama.

Kamil, I. (2020). Kemneterian PPPA Catat ada 4116 Kasus Kekerasan Anak Pada 7 Bulan Terakhir. dowlonad di https://nasional.kompas.com/read/2020/08/12/15410871/ kementerian-pppa-catat-ada-4116-kasus-kekerasan-anakdalam-7-bulan-terakhir?page $=$ all pada tanggal 02 Februari 2021

Kristianus. (2011). Nasionalisme Etnik Di Kalimantan Barat. Masyarakat Indonesia, 37(2).

Lickona, T. 2008. Pendidikan Karakter, Panduan Lengkap Mendidik Siswa Menjadi Pintar dan Baik. Bandung: Penerbit Nusa Media

Megawangi, R. 2010. Pengembangan Program Pendidikan Karakter di Sekolah: Pengalaman Sekolah Karakter. Depok: Indonesia Heritage Foundation

Muhaimin, D. 2012. Paradigma Pendidikan Islam. Bandung: PT. Remaja Rosdakarya

Mukminan, dkk. 2017. Ilmu Pengetahuan Sosial: SMP/MTs Kelas VIII. Jakarta: Kementerian Pendidikan dan Kebudayaan

Mulyasa, E. 2013. Manajemen Pendidikan Karakter. Jakarta: PT. Bumi Aksara
Maftuh, B. (2005). Implementasi Model Pembelajaran Resolusi Konflik Melalui Pendidikan Kewarganegaraan Sekolah Menengah Atas. Disertasi: Universitas Pendidikan Indonesia.

Mindes, G. 2006. Teaching Young Children Social Studies. USA: Praeger Publishers

Merton, D.,Coleman PT. (2006). The Handbook of Conflict Resolution: Theory and Practice. San Fransisco: Jossy Bass Publisher

Nadya, F., Elly Malihah, Wilodati. 2020. Kemampuan Resolusi Konflik Interpersonal dan Urgensinya pada Siswa. Societas Vol. 10, No. 1

Nazir. (2014). Metode Penelitian. Bogor: Ghalia Indonesia

NCSS. (1994). Curriculum Standards for Social Studies. Washington DC :NCSS

Permendiknas No. 22 tahun 2006 tentang Standar Isi Mata Pelajaran IPS

Prastiwi, D. 2018. Pelaksanaan Living Values Education Program (LVEP) di RA Tiara Chandra Dalam Pembentukan Karakter. E-Jurnal Prodi Teknologi Pendidikan Vol. 7 Nomor 6 Tahun 2018

Purwoko, B., dkk. 2016. Keefektifan Konseling Resolusi Konflik untuk Mengatasi Konflik Interpersonal pada Siswa Sekolah Menengah Atas. Jurnal Pendidikan Humaniora Vol. 4 No. 1, Maret 2016

Ritiauw, S. P., Maftuh, B., \& Malihah, E. (2019). Peran Guru dalam Pembelajaran Resolusi Konflik Berbasis Nilai Budaya Pela di Kota Ambon. Sosio Didaktika: Social Science Education Journal, 6 (2)

Rodiah, H., Wayan Lasmawan, Nyoman Dantes. (2018) Pengaruh Model Pembelajaran Resolusi Konflik Terhadap Sikap Sosial dan Hasil Belajar IPS Kelas V SD Gugus 2 Selong Lombok Timur. Jurnal DIDIKA: Wahana Ilmiah Pendidikan Dasar

Rusman. (2012). Model-Model Pembelajaran Mengembangkan Profesionalisme Guru. Jakarta: PT Raja Grafindo Persada.

Sari, IP., An-Nisa Apriani. 2020. Pengembangan SSP Tematik Integratif Berbasis LVEP Untuk Penguatan. Elementary School Vol. 7, No. 1 Januari 2020

Schiller, P., dan Tamera Bryant. 2002. Values Book for Chilren: 16 Moral Dasar Bagi Anak. Jakarta: PT Elex Mesia Komputindo, Kelompok Gramedia

Somantri N. 2011. Mengagasa Pembelajaran Pendidikan IPS Bandung: PT. Remaja Rosdakarya.

Sudrajat, A. (2008). Pengertian Pendekatan, Strategi, Metode, Teknik, Taktik, dan Model Pembelajaran. Sinar Baru Algensindo.

Sumaatmadja, N. 2001. Metodologi Pengajaran Ilmu Pengetahuan Sosial (IPS). Bandung: Alumni

Tafsir, A. 2010. Ilmu Pendidikan Islami. Bandung: PT. Remaja Rosdakarya

Tillman, D., Diana Hsu. 2004. Living Values Activities for Young Adults. Jakarta: Grasindo

Tillman, D. 2000. Living Values Activities for Children Ages 3-7. New York: Health Communication

Undang-Undang Nomor 35 Tahun 2014 tentang Perlindungan Anak 
Welianto, A. 2020. Kasus Kekerasan yang Dipicu Masalah Keberagaman di Indonesia. Download di https://www.kompas.com/skola/read/2020/02/06/190000 569/kasus-kekerasan-yang-dipicu-masalahkeberagaman-di-indonesia?page $=$ all pada tanggal 1 November 2020

Wiranataputra, Udin S. 2010. Konsep dan Masalah Pengajaran Ilmu Sosial Di sekolah Menegah. Jakarta: LPTK

Wijayanti, W., Agustinus Djokowidodo. 2019. Persepsi Peserta Didik Terhadap Kekerasan Verbal oleh Guru di SMP se-Kota Madiun. Fonema, Vol 2, No. 2 November 2019

Zed, M. (2008). Metode Penelitian Kepustakaan. Jakarta: Yayasan Obor Indonesia. 